\title{
Nonpolar Side Chains Affect the Photochemical Redox Reactions of Copper(II)-Amino Acid Complexes in Aqueous Solutions
}

\author{
Chen-Jui Lin, Po-Yen Wang, Yi-Liang Lin, Sheng-Te Chang, Chao-Sheng Hsu, Shu-Pao Wu, \\ and Chien-Hou $\mathrm{Wu}^{*}$
}

Cite This: ACS Omega 2021, 6, 28194-28202

Read Online

\section{ACCESS}

山ll Metrics \& More

回 Article Recommendations

(s) Supporting Information

ABSTRACT: Photochemical redox reactions of $\mathrm{Cu}(\mathrm{II})$ complexes of eight amino acid ligands (L) with nonpolar side chains have been systematically investigated in deaerated aqueous solutions. Under irradiation at $313 \mathrm{~nm}$, the intramolecular carboxylate-to-Cu(II) charge transfer within $\mathrm{Cu}$ (II)-amino acid complexes leads to $\mathrm{Cu}$ (I) formation and the concomitant decomposition of amino acids. All amino acid systems studied here can produce ammonia and aldehydes except proline. For the $1: 1 \mathrm{Cu}$ (II) complex species $(\mathrm{CuL})$, the $\mathrm{Cu}(\mathrm{I})$ quantum yields at $313 \mathrm{~nm}\left(\Phi_{\mathrm{Cu}(\mathrm{I}), \mathrm{CuL}}\right)$ vary by fivefold and in the sequence $\left(0.10 \mathrm{M}\right.$ ionic strength at $\left.25{ }^{\circ} \mathrm{C}\right)$ alanine $(0.094)>$ valine $(0.059)$, leucine (0.059), isoleucine $(0.056)$, phenylalanine $(0.057)>$ glycine $(0.052)>$ methionine $(0.032)>$ proline $(0.019)$. This trend can be rationalized by considering the stability of the carbon-centered radicals and the efficient depopulation of the photoexcited state, both of which are dependent on the side-chain structure. For the 1:2 $\mathrm{Cu}$ (II) complex species $\left(\mathrm{CuL}_{2}\right)$, the $\mathrm{Cu}(\mathrm{I})$ quantum yields exhibit a similar trend and are always less than

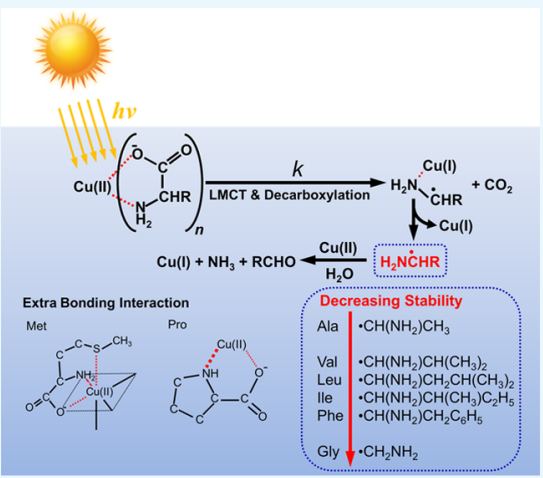
those for $\mathrm{CuL}$. The photoformation rates of ammonia, $\mathrm{Cu}(\mathrm{I})$, and aldehydes are in the ratio of 1:2.0 $\pm 0.2: 0.7 \pm 0.2$, which supports the proposed mechanism. This study suggests that the direct phototransformation of $\mathrm{Cu}(\mathrm{II})$-amino acid complexes may contribute to the bioavailable nitrogen for aquatic microorganisms and cause biological damage on cell surfaces in sunlit waters.

\section{INTRODUCTION}

The photochemical reactions of copper complexes with diverse organic ligands have received considerable attention in environmental, biological, and industrial processes. ${ }^{1-5}$ The dissolved copper in natural waters is thought to form complexes with dissolved organic matter (DOM), mainly including amino, phenolic, alcoholic, ketonic, and carboxylic groups. $^{6-11}$ Plenty of photochemical redox reactions of copper complexes can occur in sunlit waters. Several investigations have shown that the sunlight-initiated photoredox reactions of DOM-bound $\mathrm{Cu}$ (II) species may have dramatic impacts on the speciation and biogeochemical cycling of copper, which can conversely alter the toxicity, bioavailability, and transport of copper in sunlit waters. ${ }^{12-15}$

The photochemical release of ammonium from dissolved organic matter (DOM) is an important source of bioavailable nitrogen in $\mathrm{N}$-limited aquatic ecosystems and the relative abundance of individual amino acids in the DOM pool has been shown to have a strong correlation with the degradation stage and the bioavailability of DOM. ${ }^{16-21}$ Amino acids are exuded by phytoplankton in the ocean, but the chemical structure of the dissolved combined amino acids remains poorly understood. ${ }^{22}$ Several studies state that glycine is most frequently identified as the most abundant amino acid in diverse environmental scenarios. ${ }^{23,24}$ Phytochelatins, metal chelators produced by marine diatoms upon exposure to metals, are small polypeptides containing the amino acid glutamate, cysteine, and glycine. ${ }^{25,26}$ Algae play a significant role in the uptake and regulation of copper in natural waters by their surfaces (i.e., membranes and cell walls) for copper binding. In diatoms, these walls comprise a silica frustule encased in an organic coating, which is enriched in the amino acid glycine, serine, and threonine. ${ }^{27}$ Dissolved free and combined amino acids are ubiquitous in natural waters, and the photochemical degradation of amino acids through either direct or indirect photolysis has been assessed in sunlit waters. $^{28-30}$ Under solar irradiation, only tyrosine and tryptophan were subject to direct photodegradation. The addition of DOM, an important photosensitizer, can greatly enhance the indirect photodegradation of histidine, methionine, tyrosine, and tryptophan. Although the four amino acids are susceptible to photochemical degradation, the remaining common amino acids seem to be photostable in natural waters. This implies that the amino acid structure plays an important role in photoreactivity.

Received: August 9, 2021

Accepted: October 1, 2021

Published: October 13, 2021 
Table 1. Equilibrium Formation Constants, Components, and Their Stoichiometric Coefficients for the Calculated Cu(II) Complex Species ${ }^{a}$

\begin{tabular}{|c|c|c|c|c|c|c|c|c|c|c|c|c|}
\hline \multirow[b]{2}{*}{ species $^{b}$} & \multicolumn{10}{|c|}{ components } & \multirow{2}{*}{$\frac{\text { equilib. constant }}{\log _{10}(\beta)}$} & \multirow[b]{2}{*}{ notes } \\
\hline & $\mathrm{Cu}^{2+}$ & $\mathrm{H}^{+}$ & $\mathrm{Gly}^{-}$ & $\mathrm{Ala}^{-}$ & $\mathrm{Val}^{-}$ & $\mathrm{Leu}^{-}$ & $\mathrm{Ile}^{-}$ & $\mathrm{Pro}^{-}$ & $\mathrm{Phe}^{-}$ & $\mathrm{Met}^{-}$ & & \\
\hline $\mathrm{Cu}(\mathrm{Gly})^{+}$ & 1 & & 1 & & & & & & & & 8.19 & \\
\hline $\mathrm{Cu}(\mathrm{Gly})_{2}{ }^{0}$ & 1 & & 2 & & & & & & & & 15.10 & \\
\hline $\mathrm{Cu}(\mathrm{Ala})^{+}$ & 1 & & & 1 & & & & & & & 8.11 & \\
\hline $\mathrm{Cu}(\mathrm{Ala})_{2}{ }^{0}$ & 1 & & & 2 & & & & & & & 14.90 & \\
\hline $\mathrm{Cu}(\mathrm{Val})^{+}$ & 1 & & & & 1 & & & & & & 8.10 & \\
\hline $\mathrm{Cu}(\mathrm{Val})_{2}{ }^{0}$ & 1 & & & & 2 & & & & & & 14.97 & \\
\hline $\mathrm{Cu}(\mathrm{HVal})^{2+}$ & 1 & 1 & & & 1 & & & & & & 10.50 & $0.15,37^{\circ}$ \\
\hline $\mathrm{Cu}(\mathrm{Val})(\mathrm{HVal})^{+}$ & 1 & 1 & & & 2 & & & & & & 18.74 & $0.15,37^{\circ}$ \\
\hline $\mathrm{Cu}(\mathrm{Leu})^{+}$ & 1 & & & & & 1 & & & & & 8.14 & \\
\hline $\mathrm{Cu}(\mathrm{Leu})_{2}{ }^{0}$ & 1 & & & & & 2 & & & & & 15.00 & \\
\hline $\mathrm{Cu}(\text { HLeu })^{2+}$ & 1 & 1 & & & & 1 & & & & & 11.66 & $0.15,37^{\circ}$ \\
\hline $\mathrm{Cu}(\mathrm{Leu})(\mathrm{HLeu})^{+}$ & 1 & 1 & & & & 2 & & & & & 19.60 & $0.15,37^{\circ}$ \\
\hline $\mathrm{Cu}(\mathrm{Ile})^{+}$ & 1 & & & & & & 1 & & & & 8.14 & \\
\hline $\mathrm{Cu}(\mathrm{Ile})_{2}{ }^{0}$ & 1 & & & & & & 2 & & & & 15.02 & \\
\hline $\mathrm{Cu}(\mathrm{OH})(\mathrm{Ile})^{0}$ & 1 & -1 & & & & & 1 & & & & 0.66 & $0.15,37^{\circ}$ \\
\hline $\mathrm{Cu}(\text { Pro })^{+}$ & 1 & & & & & & & 1 & & & 8.84 & \\
\hline $\mathrm{Cu}(\text { Pro })_{2}{ }^{0}$ & 1 & & & & & & & 2 & & & 16.36 & \\
\hline $\mathrm{Cu}(\text { HPro })^{2+}$ & 1 & 1 & & & & & & 1 & & & 11.41 & $0.15,37^{\circ}$ \\
\hline $\mathrm{Cu}$ (Pro) $(\text { HPro })^{+}$ & 1 & 1 & & & & & & 2 & & & 20.45 & $0.15,37^{\circ}$ \\
\hline $\mathrm{Cu}(\mathrm{Phe})^{+}$ & 1 & & & & & & & & 1 & & 7.77 & \\
\hline $\mathrm{Cu}(\mathrm{Phe})_{2}{ }^{0}$ & 1 & & & & & & & & 2 & & 14.65 & \\
\hline $\mathrm{Cu}(\mathrm{Met})^{+}$ & 1 & & & & & & & & & 1 & 7.86 & \\
\hline $\mathrm{Cu}(\mathrm{Met})_{2}{ }^{0}$ & 1 & & & & & & & & & 2 & 14.51 & \\
\hline
\end{tabular}

${ }^{a}$ All equilibrium formation constants $(\beta)$ are for $1.0 \mathrm{~atm}, 25{ }^{\circ} \mathrm{C}$, and ionic strength $I=0.10 \mathrm{M}$ (except where noted otherwise). Equilibrium formation constants for all inorganic $\mathrm{Cu}(\mathrm{II})$ species are taken into consideration and details of the definition of symbols are described elsewhere. ${ }^{36}$ The $\mathrm{p} K_{\mathrm{a}}$ values of the species used here are Gly $(2.33,9.57)$, Ala $(2.33,9.71)$, Val $(2.26,9.50)$, Leu $(2.32,9.56)$, Ile (2.27, 9.59), Pro (1.90, 10.47), Phe $(2.18,9.09)$, Met $(2.16,9.08), \mathrm{H}_{3} \mathrm{PO}_{4}(1.92,6.71,11.65)$, and $\mathrm{H}_{2} \mathrm{CO}_{3} *(6.13,9.88)$, where $\mathrm{H}_{2} \mathrm{CO}_{3} * \equiv \mathrm{H}_{2} \mathrm{CO}_{3}(\mathrm{aq})+\mathrm{CO}_{2}(\mathrm{aq})\left(25{ }^{\circ} \mathrm{C}, I=\right.$ $0.10 \mathrm{M}$, and $1.0 \mathrm{~atm}) . \log _{10}\left(K_{\mathrm{w}}\right)=-13.78$ for $K_{\mathrm{w}}=\left[\mathrm{H}^{+}\right]\left[\mathrm{OH}^{-}\right]\left(25^{\circ} \mathrm{C}, I=0.10 \mathrm{M}\right.$, and $\left.1.0 \mathrm{~atm}\right) .{ }^{b} \mathrm{HVal}^{0}$, HLeu ${ }^{0}$, and $\mathrm{HPro}^{0}$ stand for the monoprotonated forms of amino acids.

The kinetics of the photolysis of $\mathrm{Cu}(\mathrm{II})$-amino acid complexes have been very intensively investigated during the last four decades. ${ }^{1,31-35}$ The ligand-to-metal charge transfer (LMCT) irradiations of $\mathrm{Cu}$ (II) complexes with glycine and alanine lead to $\mathrm{Cu}(\mathrm{I})$ formation and induce decarboxylation of the ligand to produce $\mathrm{CO}_{2}, \mathrm{NH}_{3}$, and $\mathrm{HCHO}$ and $\mathrm{CH}_{3} \mathrm{CHO}$, respectively. ${ }^{34}$ Previous studies were generally conducted to measure the average photoproduct yields or the quantum yields for $\mathrm{CuL}_{2}$, where $\mathrm{CuL}_{2}$ existed dominantly in the conditions. Very few quantum yields for individual $\mathrm{Cu}$ (II)amino acid complex species have been conducted. Therefore, a systematic assessment of the effect of amino acid ligand structure on individual quantum yields is important to evaluate the photochemical behavior of $\mathrm{Cu}(\mathrm{II})$-amino acid complexes in natural waters. To precisely determine the $\mathrm{Cu}(\mathrm{I})$ quantum yield, the experiments should be performed in the absence of oxygen. In this study, we extend our previous work to include $\mathrm{Cu}$ (II) complexes of amino acids with a series of nonpolar side chains involving methionine (Met), glycine (Gly), alanine (Ala), valine (Val), leucine (Leu), isoleucine (Ile), phenylalanine (Phe), and proline (Pro) in deaerated aqueous solution. ${ }^{36}$ The quantum yields of photoproducts for individual $\mathrm{Cu}(\mathrm{II})$-amino acid complex species would be characterized and the effects of side-chain structure and of the $\mathrm{Cu}(\mathrm{II})-$ amino acid complex stoichiometry on their quantum yields clarified. The results obtained in this study are considered to be valuable for the understanding of the LMCT mechanisms of $\mathrm{Cu}(\mathrm{II})$-amino acid complexes on cell surfaces for biological damage, $\mathrm{Cu}(\mathrm{II})$-bacteria complexes for water disinfection, and $\mathrm{Cu}(\mathrm{II})-\mathrm{DOM}$ complexes for the inhibition of triplet sensitized phototransformation. ${ }^{37-40}$

\section{RESULTS AND DISCUSSION}

2.1. Characterization of $\mathbf{C u}(\mathrm{II})$ Complexes. Table 1 summarizes $\mathrm{Cu}(\mathrm{II})$ complexes with different amino acids and their corresponding $\mathrm{p} K_{\mathrm{a}}$ values and equilibrium formation constants. Nonpolar side-chain amino acids show strong complexation ability with $\mathrm{Cu}$ (II) through the amino nitrogen and carboxylato oxygen atoms and are capable of establishing planar mono- and bis-complexes $\left(\mathrm{CuL}\right.$ and $\left.\mathrm{CuL}_{2}\right)$, which are the major species throughout the experimental ranges studied here. The $\mathrm{Cu}$ (II) speciation can be calculated from equilibrium computations with reliable equilibrium formation constants. $^{41,42}$

From equilibrium speciation calculations for the molar absorbance and photochemical experiments of each $\mathrm{Cu}(\mathrm{II})-$ amino acid solution, the $\mathrm{Cu}(\mathrm{II})$ complex species $\mathrm{CuL}$ and $\mathrm{CuL}_{2}$ constituted at least $86 \%$ for all but two experiments for leucine and proline. In most experimental conditions, inorganic $\mathrm{Cu}$ (II) species were kept at a minor fraction smaller than $10 \%$ of the total $\mathrm{Cu}(\mathrm{II})$ concentration.

The total rate of the $\mathrm{Cu}(\mathrm{I})$ photoformation for a $\mathrm{Cu}(\mathrm{II})-$ amino acid complex is dependent on two important factors: its molar absorptivity and quantum yield at $313 \mathrm{~nm}$. Molar absorptivities for individual species at a given wavelength can be expressed as 


$$
\varepsilon_{\mathrm{Cu}(\mathrm{II})}=\sum_{i}\left(\varepsilon_{i} f_{i}\right)
$$

where $\varepsilon_{\mathrm{Cu}(\mathrm{II})}$ is the experimental $\mathrm{Cu}(\mathrm{II})$-based molar absorptivity $\left(\mathrm{M}^{-1} \mathrm{~cm}^{-1}\right), \varepsilon_{\mathrm{i}}$ is the molar absorptivity of individual $\mathrm{Cu}$ (II) complexes, $\varepsilon_{\text {in }}$ is an average value for all inorganic $\mathrm{Cu}(\mathrm{II})$ species, $f_{\mathrm{i}}$ is the fraction of the total copper present as the $i$ th $\mathrm{Cu}(\mathrm{II})$ complex species (e.g., $f_{\mathrm{CuL}}$ and $f_{\mathrm{CuL}_{2}}$ ), and $f_{\text {in }}$ is the fraction of all forms of inorganic $\mathrm{Cu}$ (II) species. ${ }^{43}$ As an example, Figure 1 shows the typical UV-vis absorption

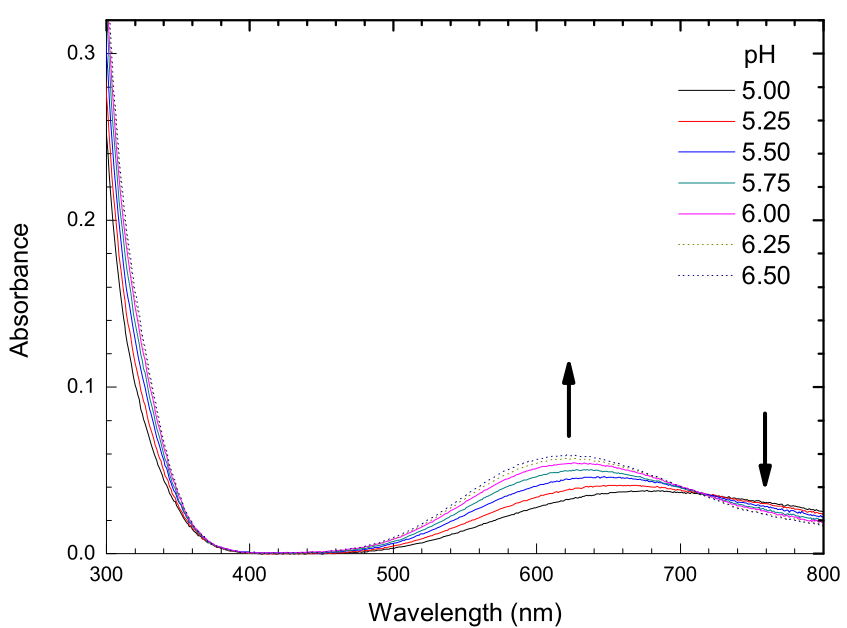

Figure 1. UV-vis spectra of $\mathrm{Cu}(\mathrm{II}) /$ Met complexes recorded as a function of $\mathrm{pH}$ (optical path length $5.00 \mathrm{~cm},[\mathrm{Cu}(\mathrm{II})]_{\mathrm{T}}=200 \mu \mathrm{M}$, $[\mathrm{Met}]_{\mathrm{T}}=2.0 \mathrm{mM}, 100 \mu \mathrm{M}$ phosphate buffer, and $\left.0.1 \mathrm{M} \mathrm{NaCl}\right)$.

spectra of $\mathrm{Cu}(\mathrm{II}) /$ Met systems. Absorbance in the $\mathrm{UV}$ region below $400 \mathrm{~nm}$ is attributed to LMCT, which can initiate the photochemical redox reactions of $\mathrm{Cu}$ (II)/Met complexes.

For the absorbance measurements of $\mathrm{Cu}$ (II)/Met systems at $313 \mathrm{~nm}, 21$ data points were measured over a wide range of solution conditions (details in the Supporting Information). Figure 2 shows the correlation between the experimental quantity and the calculated fraction of $\mathrm{Cu}$ (II) speciation $\left(f_{\mathrm{CuL}}\right)$. The best-fit values for the molar absorptivities of $\mathrm{CuL}$ and $\mathrm{CuL}_{2} \quad\left(\varepsilon_{\mathrm{CuL}}\right.$ and $\left.\varepsilon_{\mathrm{CuL}_{2}}\right)$ were determined from a

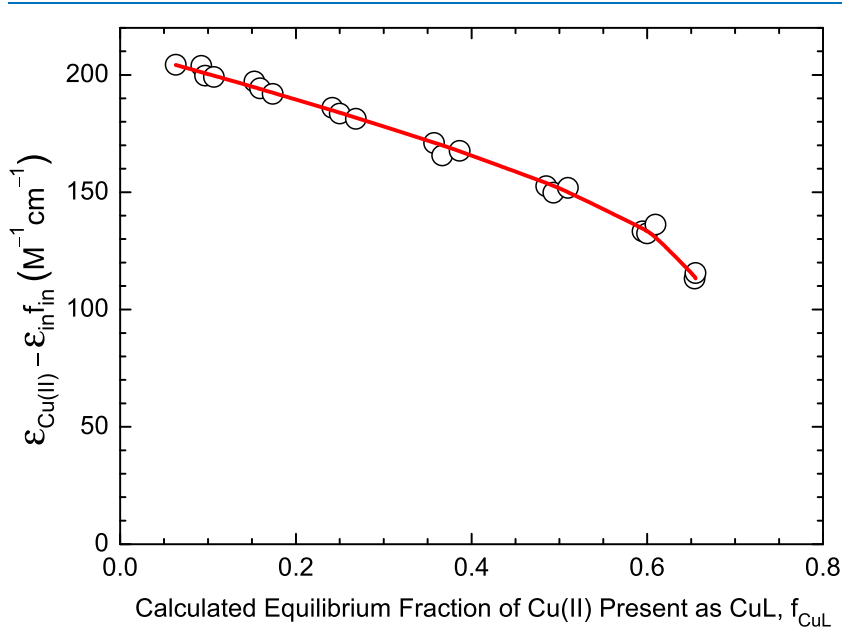

Figure 2. Experimental molar absorptivities of $\mathrm{Cu}(\mathrm{II}) /$ Met complexes at $313 \mathrm{~nm}$ as a function of the calculated equilibrium fraction of $\mathrm{Cu}(\mathrm{II})$ speciation $\left(f_{\mathrm{CuL}}\right)$ over a wide range of solution conditions. multivariate linear regression of eq 1 . In this case, the best-fit curve shown here is not a straight line as it would be if $f_{\text {in }}$ was negligible. The fitting result indicates that the molar absorptivity for $\mathrm{CuL}_{2}\left(211 \mathrm{M}^{-1} \mathrm{~cm}^{-1}\right)$ is higher than that for $\mathrm{CuL}\left(108 \mathrm{M}^{-1} \mathrm{~cm}^{-1}\right)$ in $\mathrm{Cu}(\mathrm{II}) /$ Met systems. Table 2 summarizes the molar absorptivities of individual complex species for each $\mathrm{Cu}$ (II)-amino acid system at $313 \mathrm{~nm}$. Those that exist at an isosbestic point around $300 \mathrm{~nm}$ including Gly, Ala, Val, Leu, and Ile have higher molar absorptivities (at 313 $\mathrm{nm}$ ) for CuL than that for $\mathrm{CuL}_{2}$. As listed in Table 2, the molar absorptivity increases with the increasing side-chain alkyl groups. The hyperchromic effect could be ascribed to the formation of a strong covalent-bonding interaction between amino acid and $\mathrm{Cu}$ (II), which is related to the electron density donating tendencies of the ligand. It is also noteworthy that Met and Pro have relatively greater molar absorptivities at 313 $\mathrm{nm}$. From a comparison of the spectra in the UV region with those of other amino acids, $\mathrm{Cu}$ (II)/Met complexes exhibited a broader band below $400 \mathrm{~nm}$, shown in Figure 1, and the enhancement of the absorption intensity could be attributed to the thioether group of Met. The strong $\mathrm{Cu}-\mathrm{S}$ interaction has been well-established in blue copper proteins. ${ }^{44,45}$ Unlike the primary amino acids, Pro has a secondary amine in the strained pyrrolidine ring, which results in a stronger $\mathrm{Cu}-\mathrm{N}$ bond and stability constant enhancement as listed in Table 1 . Therefore, $\mathrm{Cu}$ (II)/Pro has the highest molar absorptivity among amino acids in Table 2.

2.2. Photochemical Behavior of $\mathrm{Cu}(\mathrm{II})$ Complexes. The kinetic behavior of the $\mathrm{Cu}(\mathrm{I})$ photoformation from the $\mathrm{Cu}$ (II) complexes has been well-established. If the total absorbance is lower than 0.042 and the transformation of $\mathrm{Cu}$ (II) to $\mathrm{Cu}(\mathrm{I})$ is less than $10 \%$ of the total $\mathrm{Cu}$ (II) concentration, the total initial rate of the $\mathrm{Cu}(\mathrm{I})$ photoformation can be determined as

$$
\begin{aligned}
R_{\mathrm{Cu}(\mathrm{I})}{ }^{0} & =[\ln (10)] I_{0} D \Phi_{\mathrm{Cu}(\mathrm{I})} \varepsilon_{\mathrm{Cu}(\mathrm{II})}[\mathrm{Cu}(\mathrm{II})]_{\mathrm{T}} \\
& =j_{\mathrm{Cu}(\mathrm{I})}[\mathrm{Cu}(\mathrm{II})]_{\mathrm{T}}
\end{aligned}
$$

where $I_{0}$ is the volume-averaged incident actinic flux (einstein $\mathrm{L}^{-1} \mathrm{~s}^{-1}$ ) determined by 2-NB chemical actinometry, $D$ is the optical path length $(\mathrm{cm}), j_{\mathrm{Cu}(\mathrm{I})}$ is the apparent first-order rate constant for the $\mathrm{Cu}(\mathrm{I})$ photoformation $\left(\mathrm{s}^{-1}\right)$, and $\Phi_{\mathrm{Cu}(\mathrm{I})}$ is the experimental $\mathrm{Cu}(\mathrm{I})$ quantum yield (mole einstein $\left.{ }^{-1}\right){ }^{43}$ Figure 3 shows a series of kinetic plots of the $\mathrm{Cu}(\mathrm{I})$ photoformation for seven $\mathrm{Cu}$ (II)-amino acid systems. The slope of this plot obeys the first-order rate and reveals a good linear relationship calculated from eq 2 . The linear regression $r^{2}$ values for the first-order kinetic plots of this type were $\geq 0.98$ for all $\mathrm{Cu}$ (II)amino acid systems (92 experiments) but five experiments did not qualify.

Since the sum of the initial rates of the $\mathrm{Cu}(\mathrm{I})$ photoformation for individual $\mathrm{Cu}$ (II) complex species gives the total $\mathrm{Cu}(\mathrm{I})$ photoformation rate in the $\mathrm{Cu}$ (II)-amino acid system, the $\mathrm{Cu}(\mathrm{I})$ quantum yields for individual $\mathrm{Cu}(\mathrm{II})$ complex species can be expressed as

$$
\Phi_{\mathrm{Cu}(\mathrm{I})} \varepsilon_{\mathrm{Cu}(\mathrm{II})}=\sum_{i}\left(\Phi_{\mathrm{Cu}(\mathrm{I}), i} \varepsilon_{i} f_{i}\right)
$$

where the quantity $\Phi_{\mathrm{Cu}(\mathrm{I})} \varepsilon_{\mathrm{Cu}(\mathrm{II})}$ is an experimental value from eq 2 and the individual $\mathrm{Cu}(\mathrm{I})$ quantum yields (mole einstein ${ }^{-1}$ ) includes $\Phi_{\mathrm{Cu}(\mathrm{I}), \mathrm{CuL}}$ for $\mathrm{CuL}, \Phi_{\mathrm{Cu}(\mathrm{I}), \mathrm{CuL}_{2}}$ for $\mathrm{CuL}_{2}$, and $\Phi_{\mathrm{Cu}(\mathrm{I}) \text {,in }}$ for the average of all inorganic $\mathrm{Cu}(\mathrm{II})$ species. $^{43}$ 
Table 2. Summary of Molar Absorptivities $\left(\mathrm{M}^{-1} \mathrm{~cm}^{-1}\right)$ and $\mathrm{Cu}(\mathrm{I})$ Quantum Yields (mole einstein $\left.{ }^{-1}\right)$ for the Individual Cu(II) Complex Species at $313 \mathrm{~nm}^{a}$

\begin{tabular}{|c|c|c|c|c|c|c|c|c|}
\hline ligand & $\varepsilon_{\mathrm{CuL}}$ & $\varepsilon_{\mathrm{CuL}_{2}}$ & $\varepsilon_{\mathrm{CuL}} / \varepsilon_{\mathrm{CuL}_{2}}$ & $\Phi_{\mathrm{Cu}(\mathrm{I}), \mathrm{CuL}}$ & $\Phi_{\mathrm{Cu}(\mathrm{I}), \mathrm{CuL}_{2}}$ & $\Phi_{\mathrm{Cu}(\mathrm{I}), \mathrm{CuL}} / \Phi_{\mathrm{Cu}(\mathrm{I}), \mathrm{CuL}_{2}}$ & $\left(\varepsilon_{\mathrm{CuL}}\right)\left(\Phi_{\mathrm{Cu}(\mathrm{I}), \mathrm{CuL}}\right)$ & $\left(\varepsilon_{\mathrm{CuL}_{2}}\right)\left(\Phi_{\mathrm{Cu}(\mathrm{I}), \mathrm{CuL}_{2}}\right)$ \\
\hline Gly & $30 \pm 2$ & $20 \pm 1$ & 1.5 & $0.052 \pm 0.014$ & $0.033 \pm 0.013$ & 1.6 & $1.56 \pm 0.40$ & $0.65 \pm 0.25$ \\
\hline $\mathrm{Ala}^{b}$ & $40 \pm 4$ & $29 \pm 2$ & 1.4 & $0.094 \pm 0.014$ & $0.064 \pm 0.012$ & 1.5 & $3.74 \pm 0.43$ & $1.87 \pm 0.32$ \\
\hline Val & $66 \pm 1$ & $58 \pm 1$ & 1.1 & $0.059 \pm 0.012$ & $0.039 \pm 0.008$ & 1.5 & $3.88 \pm 0.76$ & $2.24 \pm 0.49$ \\
\hline Leu & $62 \pm 4$ & $51 \pm 3$ & 1.2 & $0.059 \pm 0.017$ & $0.043 \pm 0.018$ & 1.4 & $3.66 \pm 1.05$ & $2.18 \pm 0.91$ \\
\hline Ile & $71 \pm 4$ & $64 \pm 2$ & 1.1 & $0.056 \pm 0.006$ & $0.046 \pm 0.005$ & 1.2 & $4.00 \pm 0.39$ & $2.97 \pm 0.30$ \\
\hline Phe & $74 \pm 2$ & $85 \pm 1$ & 0.9 & $0.057 \pm 0.016$ & $0.046 \pm 0.007$ & 1.2 & $4.19 \pm 1.17$ & $3.90 \pm 0.63$ \\
\hline Met & $108 \pm 7$ & $211 \pm 4$ & 0.5 & $0.032 \pm 0.008$ & $0.016 \pm 0.003$ & 2.0 & $3.46 \pm 0.84$ & $3.45 \pm 0.56$ \\
\hline Pro & $145 \pm 5$ & $250 \pm 3$ & 0.6 & $0.019 \pm 0.005$ & $0.011 \pm 0.002$ & 1.7 & $2.81 \pm 0.67$ & $2.78 \pm 0.52$ \\
\hline
\end{tabular}

${ }^{a}$ Best value $\pm 1 \mathrm{SD}$ for $0.10 \mathrm{M}$ ionic strength $(\mathrm{NaCl})$ at $25{ }^{\circ} \mathrm{C}$. The wide range of solution conditions is provided in the Supporting Information. ${ }^{b}$ Reference 36 .

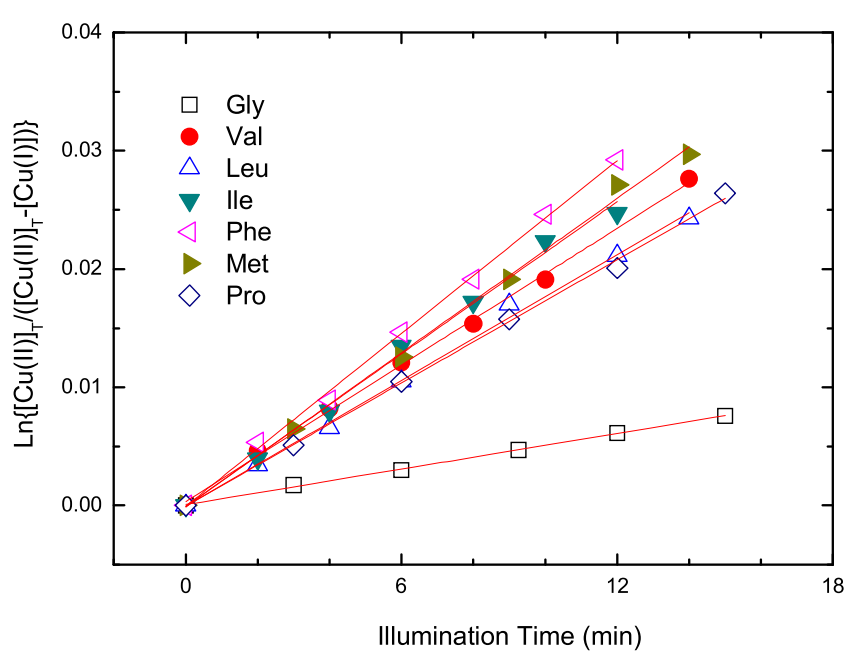

Figure 3. Correlation of $\mathrm{Cu}(\mathrm{I})$ photoformation at $313 \mathrm{~nm}$ with illumination time. $\mathrm{Cu}(\mathrm{II})-$ amino acid systems with $[\mathrm{Cu}(\mathrm{II})]_{\mathrm{T}}=50$ $\mu \mathrm{M}$, [amino acid $]_{\mathrm{T}}=2.0 \mathrm{mM}$, and $\mathrm{pH}=6.00(100 \mu \mathrm{M}$ phosphate buffer and $0.1 \mathrm{M} \mathrm{NaCl}$ ).

The initial photoformation rates of ammonia and aldehydes under previous conditions show similar expression forms as in eq 3 . As an example, Figure 4 displays the relationship between

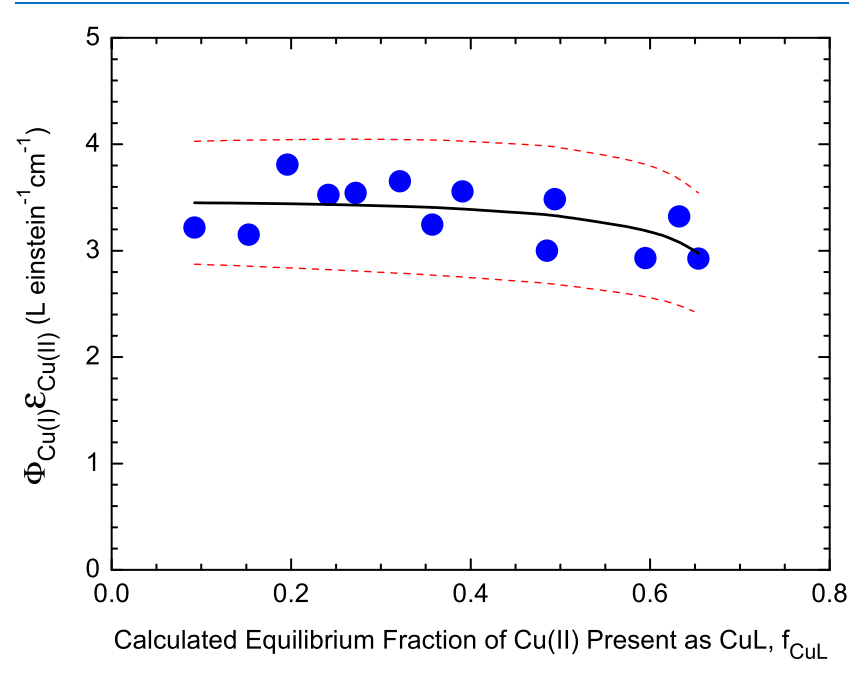

Figure 4. Measured photochemical parameters of $\mathrm{Cu}(\mathrm{II}) / \mathrm{Met}$ complexes as a function of the calculated fraction of $\mathrm{Cu}$ (II) speciation $\left(f_{\mathrm{CuL}}\right)$ over a wide range of solution conditions. The dashed red lines indicate the $95 \%$ confidence interval. the photochemical parameters $\left(\Phi_{\mathrm{Cu}(\mathrm{I})} \varepsilon_{\mathrm{Cu}(\mathrm{II})}\right)$ and the calculated fraction of $\mathrm{Cu}(\mathrm{II})$ speciation $\left(f_{\mathrm{CuL}}\right)$ for $\mathrm{Cu}(\mathrm{II}) /$ Met systems. The best-fit values were determined from a multivariate linear regression of eq 3 . These results demonstrate that the rate of the $\mathrm{Cu}(\mathrm{I})$ photoformation is mainly governed by the $\mathrm{Cu}$ (II) speciation (see the Supporting Information for the remaining amino acid systems). The $\mathrm{Cu}(\mathrm{I})$ quantum yields of individual complexes for each $\mathrm{Cu}$ (II)-amino acid system studied here are independent of the solution composition, as presented in Table 2 . The observed reactivity of the $\mathrm{Cu}(\mathrm{I})$ quantum yields varies by fivefold for $\mathrm{CuL}$ and by sixfold for $\mathrm{CuL}_{2}$. It is noteworthy that the $\mathrm{Cu}(\mathrm{I})$ quantum yields for $\mathrm{Cu}$ (II)-amino acid complexes are lower than those for $\mathrm{Cu}$ (II)-dicarboxylate complexes due to the efficient depopulation of the photoexcited state by the strong $\mathrm{Cu}-\mathrm{N}$ bond. ${ }^{46,47}$

2.3. Effect of Amino Acid Side-Chain Structure on the Quantum Yield. Because $\mathrm{Cu}(\mathrm{II})$ complexes of amino acids with different nonpolar side chains have a similar coordination structure involving stable five-membered chelates through the $\alpha$-amine and carboxylate moieties, a proposed mechanism for the photochemical redox reaction of $\mathrm{Cu}(\mathrm{II})$-amino acid complexes could be illustrated in Figure 5. Briefly, this mechanism involves an efficient LMCT process by decarboxylation, photoformation of $\mathrm{Cu}(\mathrm{I})$ and carbon-centered radicals, and subsequent reaction of the carbon-centered radicals to form $\mathrm{Cu}(\mathrm{I}), \mathrm{NH}_{3}$, and aldehydes. When the steady-state approximation is applied to the intermediates $[\mathrm{Cu}(\mathrm{I})$ $\left.\mathrm{NH}_{2} \dot{\mathrm{C}} \mathrm{HR}\right]$ and $\left[\mathrm{NH}_{2} \dot{\mathrm{C}} \mathrm{HR}\right]$, the decarboxylation rate of the direct photochemical process is equal to the oxidation rate of carbon-centered radicals with $\mathrm{Cu}$ (II) complexes. Based on this assumption, the irradiations of $\mathrm{Cu}$ (II)/Gly and Ala complexes induce decarboxylation of the ligands to carbon dioxide, ammonia, and aldehydes in the ratio of $2: 1: 1$ in the previous final product analysis. ${ }^{34,36}$ As listed in Table 3, the results are similar to those in the $\mathrm{Cu}(\mathrm{II}) / \mathrm{Val}$, Leu, Ile, Phe, and Met systems giving the formation rates of $\mathrm{Cu}(\mathrm{I}), \mathrm{NH}_{3}$, and aldehydes in the ratio of $2.0 \pm 0.2: 1: 0.7 \pm 0.2$. Neither ammonia nor aldehyde was detected in the $\mathrm{Cu}$ (II)/Pro system probably due to the formation of secondary amines.

In Figure 5, the trans form of the $1: 2$ complex $\left(\mathrm{CuL}_{2}\right)$ is depicted according to the study that about $60 \%$ of the complexes were present as the trans isomer in aqueous solutions with $0.10 \mathrm{M} \mathrm{KNO}_{3}$ as the background. ${ }^{48}$ The previous study indicates that a cis-trans isomer equilibrium occurs rapidly in aqueous solutions and the cis-trans ratio is little affected by the nature of the side chain. It is worth noting that the addition of a salt background has an influence on the 

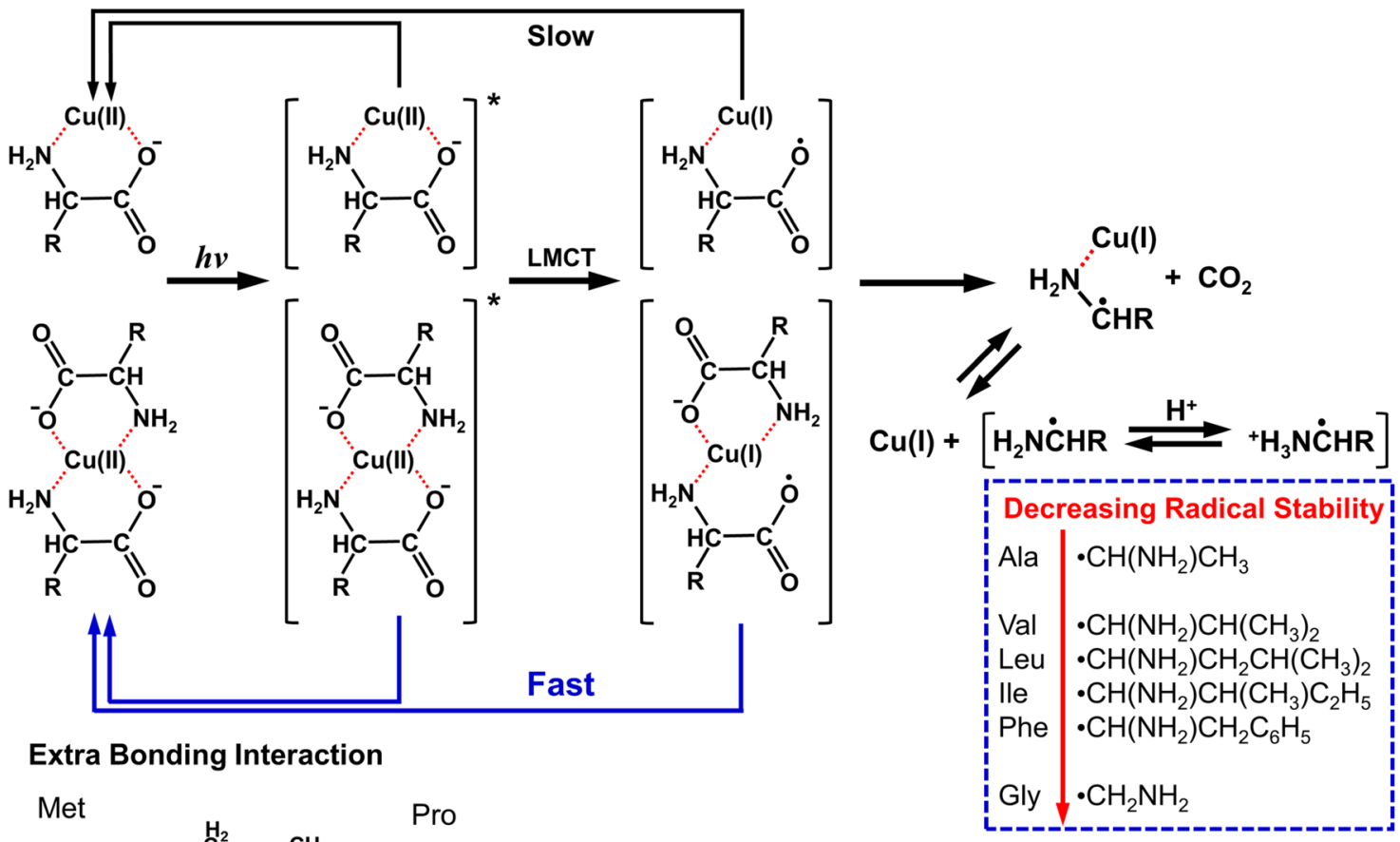

Extra Bonding Interaction

Met

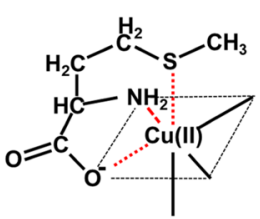

Pro

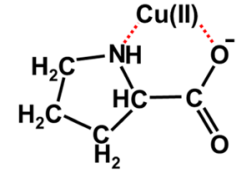

$\mathrm{Cu}(\mathrm{II})+\mathrm{H}_{2} \mathrm{~N} \dot{\mathrm{C}} \mathrm{HR} \longrightarrow \mathrm{Cu}(\mathrm{I})+\mathrm{H}_{2} \mathrm{~N} \stackrel{+}{\mathrm{C}} \mathrm{HR}$

$\mathrm{H}_{2} \mathrm{~N}_{\mathrm{C}}^{\mathrm{C}} \mathrm{HR} \rightleftharpoons \mathrm{HN}=\mathrm{CHR}+\mathrm{H}^{+}$

$\mathrm{HN}=\mathrm{CHR}+\mathrm{H}_{2} \mathrm{O} \longrightarrow \mathrm{NH}_{3}+\mathrm{RCHO}$

Figure 5. Proposed mechanism for the photochemical redox reaction of $\mathrm{Cu}(\mathrm{II})$-amino acid complexes. The amino acids studied differ in the sidechain $\mathrm{R}$.

Table 3. Summary of the Ratio of the Total Initial Photoformation Rates of Cu(I) to Ammonia and Aldehydes for Cu(II)Amino Acid Complexes at $313 \mathrm{~nm}^{a}$

$\begin{array}{lllllllll} & \text { Gly } & \mathrm{Ala}^{b} & \text { Val } & \text { Leu } & \text { Ile } & \text { Phe } & \text { Met } & \text { Pro } \\ R_{\mathrm{Cu}(\mathrm{I})}{ }^{0} / R_{\mathrm{NH}_{3}}{ }^{0} & 1.70 & 1.74 & 2.15 & 2.18 & 2.07 & 1.90 & 2.09 & \mathrm{ND}^{c} \\ R_{\mathrm{Cu}(\mathrm{I})}{ }^{0} / R_{\mathrm{RCHO}}{ }^{0} & 1.62 & 2.58 & 2.56 & 3.17 & 3.02 & 2.43 & 1.89 & \mathrm{ND}\end{array}$

${ }^{a}$ The wide range of solution conditions is provided in Table S1. ${ }^{b}$ Reference $36 .{ }^{c}$ ND: not detected.

cis-trans isomer equilibrium in favor of the formation of the cis isomer. ${ }^{49}$

As can be seen in Table 2, the $\mathrm{Cu}(\mathrm{I})$ quantum yields vary in the order Ala $>$ Val, Leu, Ile, Phe $>$ Gly $>$ Met $>$ Pro. The rate of decarboxylation is strongly dependent upon the stability of the carbon-centered radicals, which is expected to alter the overall quantum yield of the photoproducts. The textbooklevel view of radical stability follows the order tertiary > secondary $>$ primary $>$ methyl, which results from the modestly stabilizing hyperconjugation with an adjacent alkyl group. ${ }^{50}$ The aminomethyl radical ${ }^{\bullet} \mathrm{CH}_{2} \mathrm{NH}_{2}$, derived from decarboxylation of the glycine radical, is expected to be relatively less stable due to its lower ordinality. However, it is quite challenging to predict the stability of the same primary radicals that are derived from decarboxylation of alanine, valine, leucine, isoleucine, and phenylalanine.

The thermodynamic stability of carbon-centered radicals has various types of definitions, and one of the most used definitions is based on isodesmic hydrogen-transfer reactions where the reaction enthalpy of this process is often expressed as the radical stabilization energy (RSE). ${ }^{51}$ The RSE values are commonly negative for radicals, which are relatively more stable than the methyl radical ${ }^{\circ} \mathrm{CH}_{3}$. Thus, as a reference system, the RSE of the methyl radical ${ }^{\bullet} \mathrm{CH}_{3}$ is $0 \mathrm{~kJ} \mathrm{~mol}^{-1}$. All RSE values used in this article are provided by Hioe and Zipse, who used the G3(MP2)-RAD method. This method has been successfully applied to estimate the stability of the radical species. ${ }^{51-53}$ The RSE values for the ethyl radical ${ }^{\bullet} \mathrm{CH}_{2} \mathrm{CH}_{3}$, npropyl radical ${ }^{\circ} \mathrm{CH}_{2} \mathrm{CH}_{2} \mathrm{CH}_{3}, n$-butyl radical - $\mathrm{CH}_{2} \mathrm{CH}_{2} \mathrm{CH}_{2} \mathrm{CH}_{3}$, 2-methylprop-1-yl radical ${ }^{\circ} \mathrm{CH}_{2} \mathrm{CH}$ $\left(\mathrm{CH}_{3}\right)_{2}$, and 2-phenyleth-1-yl radical ${ }^{\circ} \mathrm{CH}_{2} \mathrm{CH}_{2} \mathrm{C}_{6} \mathrm{H}_{5}$ are $-13.5,-12.2,-12.2,-10.6$, and $-10.4 \mathrm{~kJ} \mathrm{~mol}^{-1}$ relative to the methyl radical ${ }^{\bullet} \mathrm{CH}_{3}$, respectively. Increasing the size of the attached alkyl group may result in a small but notable reduction in radical stability. This trend implies that the hyperconjugative effect through the interaction of the unpaired spin with adjacent bonds is stronger than the inductive electron withdrawal effect of the alkyl groups. Noticeably, the remote $\pi$-orbitals of the aromatic ring do not lead to more efficient stabilization. On the other hand, the stability of alkyl radicals could be greatly enhanced through a lone-pair donation. Amino-substituted radicals appear to be quite important in enhancing the stability of aminomethyl radical ${ }^{\circ} \mathrm{CH}_{2} \mathrm{NH}_{2}\left(\mathrm{RSE}=-44.9 \mathrm{~kJ} \mathrm{~mol}^{-1}\right)$ and 1-aminoethyl radical 
- $\mathrm{CHNH}_{2} \mathrm{CH}_{3}\left(\mathrm{RSE}=-49.9 \mathrm{~kJ} \mathrm{~mol}^{-1}\right)$, both of which are much more stable than the methyl radical ${ }^{\bullet} \mathrm{CH}_{3}$ and the ethyl radical ${ }^{\bullet} \mathrm{CH}_{2} \mathrm{CH}_{3}$, respectively. The experimentally measured $\mathrm{RSE}$ value for ${ }^{\bullet} \mathrm{CHNH}_{2} \mathrm{CH}_{3}$ is $-62.3 \mathrm{~kJ} \mathrm{~mol}^{-1}$, which leads to much larger stabilization energy and further confirms that the carbon-centered radical derived from the decarboxylation of alanine is the most stable one among the eight amino acids. ${ }^{54}$ Although the interplay of the amino group attached to the radical center results in much more stable carbon-centered radicals, the stability of amino-substituted radicals follows the same trend as the radicals listed above. Therefore, the stability of the carbon-centered radicals follows the trend ${ }^{\bullet} \mathrm{CH}\left(\mathrm{NH}_{2}\right)$ $\mathrm{CH}_{3}>{ }^{\bullet} \mathrm{CH}\left(\mathrm{NH}_{2}\right) \mathrm{CH}\left(\mathrm{CH}_{3}\right)_{2} \sim{ }^{\bullet} \mathrm{CH}\left(\mathrm{NH}_{2}\right) \mathrm{CH}_{2} \mathrm{CH}\left(\mathrm{CH}_{3}\right)_{2} \sim$ - $\mathrm{CH}\left(\mathrm{NH}_{2}\right) \mathrm{CH}\left(\mathrm{CH}_{3}\right) \mathrm{C}_{2} \mathrm{H}_{5} \sim{ }^{\circ} \mathrm{CH}\left(\mathrm{NH}_{2}\right) \mathrm{CH}_{2} \mathrm{C}_{6} \mathrm{H}_{5}>$ - $\mathrm{CH}_{2} \mathrm{NH}_{2}$, which are derived from decarboxylation of the Ala, Val, Leu, Ile, Phe, and Gly radicals, respectively. Figure 6

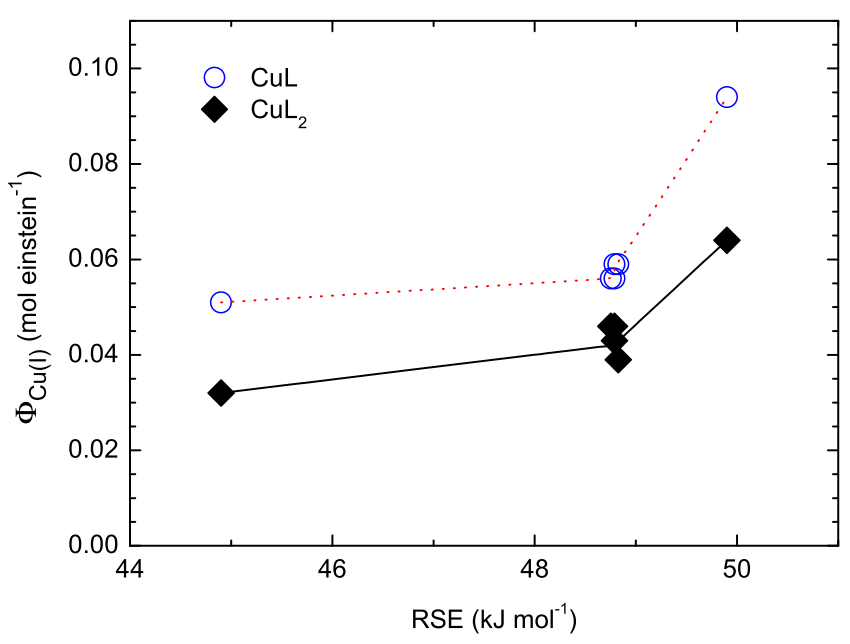

Figure 6. Correlation between the individual $\mathrm{Cu}(\mathrm{I})$ quantum yield and RSE of relative ligands.

shows the correlation between RSE and quantum yield. The orders in $\mathrm{Cu}(\mathrm{I})$ quantum yields of $\mathrm{Cu}(\mathrm{II})$-amino acid complexes are amazingly the same as the trend of the stability of the carbon-centered radicals.

$\mathrm{Cu}(\mathrm{II})$-amino acid complexes involve a common fivemembered chelate ring by N,O-chelation as shown in Figure 5, but Met and Pro systems have a little bit different binding properties with $\mathrm{Cu}(\mathrm{II})$, which result in a dramatic change of the $\mathrm{Cu}(\mathrm{I})$ quantum yields. The thioether group of Met could interact with $\mathrm{Cu}(\mathrm{II})$ to form an additional $\mathrm{Cu}-\mathrm{S}$ bond, although the interaction is weak and does not contribute importantly to the complex stability. The strain of the secondary $\mathrm{N}$-donor of Pro could interact with $\mathrm{Cu}(\mathrm{II})$ to form a much stronger $\mathrm{Cu}-\mathrm{N}$ bond, and this interaction does enhance the stability constant as listed in Table 1 . Both $\mathrm{Cu}-\mathrm{S}$ and stronger $\mathrm{Cu}-\mathrm{N}$ bonds could provide an efficient pathway for the nonradiative electronic relaxation of the LMCT state. Therefore, in addition to the stability of the carbon-centered radicals, the efficient depopulation of the photoexcited state is also a significant factor affecting the $\mathrm{Cu}(\mathrm{I})$ quantum yields for Met and Pro systems.

2.4. Photoreaction Rate Constants in Sunlight. The photoreaction rate constants for the photoformation of $\mathrm{Cu}(\mathrm{I})$ from $\mathrm{Cu}(\mathrm{II})$-amino acid complexes in sunlight (solar zenith angle $=30^{\circ}$ ) are shown in Table 4 and the half-lives vary by a factor of 9 between 10 and $93 \mathrm{~h}$. The photoreactivity of
Table 4. Summary of Photoreaction Rate Constants in Sunlight

\begin{tabular}{lcccc} 
ligand & $j_{\mathrm{CuL} \rightarrow \mathrm{Cu}(\mathrm{I})}, \mathrm{sec}^{-1}$ & half-life $(\mathrm{h})$ & $j_{\mathrm{CuL}_{2} \rightarrow \mathrm{Cu}(\mathrm{I})}, \mathrm{sec}^{-1}$ & half-life $(\mathrm{h})$ \\
Gly & $4.45 \times 10^{-6}$ & 43 & $2.06 \times 10^{-6}$ & 93 \\
Ala & $1.17 \times 10^{-5}$ & 16 & $5.35 \times 10^{-6}$ & 36 \\
Val & $1.06 \times 10^{-5}$ & 18 & $8.41 \times 10^{-6}$ & 23 \\
Leu & $1.43 \times 10^{-5}$ & 13 & $6.84 \times 10^{-6}$ & 28 \\
Ile & $1.09 \times 10^{-5}$ & 18 & $8.18 \times 10^{-6}$ & 24 \\
Phe & $1.33 \times 10^{-5}$ & 14 & $1.18 \times 10^{-5}$ & 16 \\
Met & $1.73 \times 10^{-5}$ & 11 & $1.93 \times 10^{-5}$ & 10 \\
Pro & $9.46 \times 10^{-6}$ & 20 & $7.61 \times 10^{-6}$ & 25 \\
\hline
\end{tabular}

$\mathrm{Cu}$ (II)-amino acid complexes in sunlight is dependent upon both their quantum yields and molar absorptivities. Therefore, although the $\mathrm{Cu}(\mathrm{II}) / \mathrm{Ala}$ complex reacts with the highest quantum yield among the systems studied, the shortest half-life is calculated for the $\mathrm{Cu}(\mathrm{II}) /$ Met complex due to its greater molar absorptivity. It implies that the direct phototransformation of $\mathrm{Cu}$ (II)/Met complexes needs to be considered in sunlit waters. Yet, a general inverse relationship between abundances of amino acids and thermodynamic free energies for the synthesis of each amino acid has been proposed. ${ }^{55}$ The longest half-life for the $\mathrm{Cu}$ (II)/Gly complex might be reflective of its most abundance in aquatic environments. Furthermore, most $\mathrm{CuL}$ complexes have higher photoactivities than $\mathrm{CuL}_{2}$ complexes, which could be ascribed to the $\mathrm{Cu}$ (II)-stabilizing effect of the second ligand, shown in Table 2. Generally, $\mathrm{CuL}$ is a predominant species in natural waters where copper is typically found in nanomolar concentrations. This implies that the photoreactivity of $\mathrm{Cu}(\mathrm{II})$-amino acid complexes is underestimated if the evaluation is based on previous studies where $\mathrm{CuL}_{2}$ is the major species. In the presence of oxygen, the photoreduced $\mathrm{Cu}(\mathrm{I})$ can easily react with oxygen to reform $\mathrm{Cu}$ (II) ${ }^{56}$ Nevertheless, the photoformation of $\mathrm{Cu}(\mathrm{I})$ observed in deaerated solution is still related to the photodegradation of amino acids in the solution containing oxygen. The photoformation rate constants of $\mathrm{NH}_{3}$ and aldehydes in air-saturated solutions could be approximately estimated from Table 4, with related values divided by 2 . Because $\mathrm{Cu}$ (II) can become an effective catalyst for the degradation of amino acids in the presence of oxygen, the calculated photoformation rate constants of $\mathrm{NH}_{3}$ and aldehydes would be lower bounds in sunlit waters.

The degradation of amino acids may significantly influence the cycling of carbon and nitrogen in the upper column water. In the presence of oxygen, the photoreduced $\mathrm{Cu}(\mathrm{I})$ can easily react with oxygen to reform $\mathrm{Cu}(\mathrm{II})$; thus, the photocatalytic redox cycle of copper can enhance the degradation of amino acids. Our preliminary data show that the photoformation rates of ammonia and aldehydes from $\mathrm{Cu}(\mathrm{II})$-amino acid complexes in an air-saturated solution increase slightly by 10-20\% compared with those in deaerated solution. Although it is not known how the photoreactivity of amino acids with different side chains is affected if they are part of a larger macromolecule (e.g., algal component, cell membrane, or DOM), our results provide a useful starting point for studies in more complex systems.

In the presence of trace amounts of copper, the strong $\mathrm{Cu}(\mathrm{II})-\mathrm{DOM}$ complexes can undergo redox transformations to form $\mathrm{Cu}(\mathrm{I})$ species and may cause the inhibition of the triplet excited state of DOM. ${ }^{37-39}$ The indirect DOMphotosensitized degradation of dissolved free amino acids 
may greatly reduce; on the other hand, the direct phototransformation of $\mathrm{Cu}$ (II)-amino acid complexes needs to be considered and may contribute to the bioavailable nitrogen for aquatic microorganisms and cause biological damage on cell surfaces in sunlit waters. Overall, this study provides further insight into the effect of side-chain structure on the direct phototransformation of $\mathrm{Cu}(\mathrm{II})$-amino acid complexes and improves our assessment of the oxidative destruction of the copper-binding sites on DOM, cell, or algal surfaces in sunlit waters.

\section{CONCLUSIONS}

Our study reveals that the side-chain structure and the $\mathrm{Cu}$ (II) complex stoichiometry play an important role in the photolysis of $\mathrm{Cu}$ (II)-amino acid complexes. In deaerated solution, the $\mathrm{Cu}(\mathrm{I})$ quantum yields follow the trend of Ala $>$ Val, Leu, Ile, and Phe > Gly > Met > Pro, which can be rationalized by considering the stability of the carbon-centered radicals and the efficient depopulation of the photoexcited state. The relative order of producing $\mathrm{Cu}(\mathrm{I})$ in deaerated solution parallels the one producing ammonia and aldehydes in deaerated or air-saturated solution. Therefore, the photoformation of $\mathrm{Cu}(\mathrm{I})$ in deaerated solution is a useful indicator to predict the photodegradation of amino acids when $\mathrm{Cu}(\mathrm{II})-$ amino acid species exist in natural waters.

\section{EXPERIMENTAL SECTION}

4.1. Materials and Solution Preparation. All of the ligands used were reagent or analytical grade and obtained from Fluka (Buchs, SG, Switzerland): $>99 \%$ pure for glycine (Gly) and L-phenylalanine (Phe) and $>99.5 \%$ pure for Lproline (Pro), L-methionine (Met), L-valine (Val), L-leucine (Leu), and L-isoleucine (Ile). 2,4-Dinitrophenylhydrazine (DNPH) (>97\%) was obtained from Sigma (St. Louis, MO). Bathocuproine (sulfonated sodium salt) was from GFS. 2-Nitrobenzaldehyde (2-NB > 98\%) was from Aldrich. Ultrapure water $(\geq 18.2 \mathrm{M} \Omega \cdot \mathrm{cm}$ resistivity) was generated by a Milli-Q water purification system (Millipore, Bedford, MA) for all solutions. Equilibrium concentrations of $\mathrm{Cu}(\mathrm{II})$-amino acid complex species were computed using Visual MINTEQ. 3.0 program. $^{57,58}$ Ionic strength corrections and equilibrium formation constants used for all inorganic $\mathrm{Cu}$ (II) species were taken into consideration and details of the methodologies used are described elsewhere. ${ }^{36}$ The experimental solution conditions were optimized from calculations and summarized in Table S1.

4.2. Analytical Equipment and Measurements. Absorbance measurements were performed using a Varian Cary 50 Bio UV-vis spectrophotometer. Photochemical experiments and chemical actinometry were conducted in $5.00 \mathrm{~cm}$ quartz cuvettes (Spectrocell Inc.) using a monochromatic illumination system (Spectral Energy Corp.) with a high-pressure $200 \mathrm{~W} \mathrm{Hg}-\mathrm{Xe}$ lamp (Ushio UXM 200H) emitting at $313 \mathrm{~nm}$ instead of sunlight in the photochemical reaction experiments as described previously. ${ }^{36}$ Spectrophotometric determination of $\mathrm{Cu}(\mathrm{I})$ was performed with the bathocuproine disulfonate (BCS) method based on the molar absorptivity of the $\mathrm{Cu}(\mathrm{I})$-bathocuproine complex at $484 \mathrm{~nm}$ of $1.24 \times 10^{4} \mathrm{M}^{-1} \mathrm{~cm}^{-1}$. ${ }^{46,59}$ Ammonia was determined by purge-and-trap ion chromatography developed previously. $^{60,61}$ A modified HPLC-DNPH method was used to determine aldehydes in waters containing $\mathrm{Cu}(\mathrm{II})$ ion. $^{62} 2$ -
Nitrobenzaldehyde (2-NB) was chosen as an actinometer for the monochromatic illumination system with a quantum yield of $0.41 \pm 0.02$ at $313 \mathrm{~nm}$ in an aqueous solution. ${ }^{63}$ The measured experimental values of the volume-averaged incident actinic flux $I_{0}$ at $313 \mathrm{~nm}$ were between 0.63 and 0.87 $\mu$ (einstein) $\mathrm{L}^{-1} \mathrm{~s}^{-1}$ for these experiments. All $\mathrm{pH}$ measurements were made using a Radiometer Analytical Ioncheck 45 meter combined with a glass electrode (Mettler Toledo Inlab 439/120). The $\mathrm{pH}$ electrode was calibrated periodically using

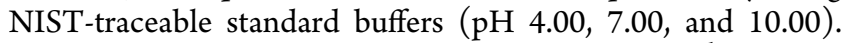
The apparent first-order rate constant $\left(j_{\mathrm{i} \rightarrow \mathrm{Cu}(\mathrm{I})}, \mathrm{s}^{-1}\right)$ for the photoformation of $\mathrm{Cu}(\mathrm{I})$ from a given individual $\mathrm{Cu}(\mathrm{II})$ complex species in terrestrial sunlight was estimated by integrating eq 4 over the wavelength range $290<\lambda \leq 340 \mathrm{~nm}$

$$
j_{i \rightarrow \mathrm{Cu}(\mathrm{I})}=\int\left\{[\ln (10)]\left[\Phi_{\mathrm{Cu}(\mathrm{I}), \mathrm{i}}(\lambda)\right]\left[\varepsilon_{\mathrm{Cu}(\mathrm{II}), \mathrm{i}}(\lambda)\right]\left[I^{\prime}(\lambda)\right]\right\} d \lambda
$$

where values of $I^{\prime}(\lambda) \mathrm{d} \lambda$ are published spherically integrated solar irradiance values over a specified wavelength range for a solar zenith angle of $30^{\circ}$, values of $\varepsilon_{\mathrm{Cu}(\mathrm{II}), \mathrm{i}}(\lambda)$ were calculated from the measured absorption spectra $290<\lambda \leq 340 \mathrm{~nm}$, and values of $\Phi_{\mathrm{Cu}(\mathrm{I}), \mathrm{i}}(\lambda)$ were obtained from $\Phi_{\mathrm{Cu}(\mathrm{I}), \mathrm{i}}$ at $313 \mathrm{~nm} .{ }^{35,64}$ As a conservative estimate, it was assumed that $\Phi_{\mathrm{Cu}(\mathrm{I}), \mathrm{i}}(\lambda)=$ $\Phi_{\mathrm{Cu}(\mathrm{I}), \mathrm{i}}(313)$ for $\lambda \leq 313 \mathrm{~nm}$ and $\Phi_{\mathrm{Cu}(\mathrm{I}), \mathrm{i}}(\lambda)=\Phi_{\mathrm{Cu}(\mathrm{I}), \mathrm{i}}(313)$. $\left[\varepsilon_{\mathrm{i}}(\lambda) / \varepsilon_{\mathrm{i}}(313)\right]$ for $313<\lambda \leq 340 \mathrm{~nm}$.

\section{ASSOCIATED CONTENT}

\section{sI Supporting Information}

The Supporting Information is available free of charge at https://pubs.acs.org/doi/10.1021/acsomega.1c04277.

Details of the experimental solution conditions used for this study (Table S1); the molar absorptivities and calculated equilibrium speciation for seven amino acid systems (Tables S2-S8); the quantum yields and calculated equilibrium speciation for seven amino acid systems (Table S9-S15); comparison of the measured and calculated molar absorptivities (Figure S1); and comparison of the measured and calculated photochemical parameters (Figure S2) (PDF)

\section{AUTHOR INFORMATION}

\section{Corresponding Author}

Chien-Hou Wu - Department of Biomedical Engineering and Environmental Sciences, National Tsing Hua University, Hsinchu 30013, Taiwan; Institute of Analytical and Environmental Sciences, National Tsing Hua University, Hsinchu 30013, Taiwan; O orcid.org/0000-0001-52432700; Phone: 886-3-5715131; Email: chwu@ mx.nthu.edu.tw; Fax: 886-3-5718649

\section{Authors}

Chen-Jui Lin - Department of Biomedical Engineering and Environmental Sciences, National Tsing Hua University, Hsinchu 30013, Taiwan

Po-Yen Wang - Department of Civil Engineering, Widener University, Chester, Pennsylvania 19013, United States

Yi-Liang Lin - Department of Biomedical Engineering and Environmental Sciences, National Tsing Hua University, Hsinchu 30013, Taiwan

Sheng-Te Chang - Department of Biomedical Engineering and Environmental Sciences, National Tsing Hua University, Hsinchu 30013, Taiwan 
Chao-Sheng Hsu - Department of Biomedical Engineering and Environmental Sciences, National Tsing Hua University, Hsinchu 30013, Taiwan

Shu-Pao Wu - Department of Applied Chemistry, National Yang Ming Chiao Tung University, Hsinchu 30010, Taiwan; (1) orcid.org/0000-0002-4424-5486

Complete contact information is available at: https://pubs.acs.org/10.1021/acsomega.1c04277

\section{Notes}

The authors declare no competing financial interest.

\section{ACKNOWLEDGMENTS}

We are grateful to the anonymous reviewers for their kind and useful comments. This study was supported by the Ministry of Science and Technology of Taiwan (the Republic of China) under Grant Numbers: NSC 100-2113-M-007-004, NSC 1012113-M-007-011, and MOST 103-2113-M-007-006.

\section{REFERENCES}

(1) Sýkora, J. Photochemistry of copper complexes and their environmental aspects. Coord. Chem. Rev. 1997, 159, 95-108.

(2) Cieśla, P.; Kocot, P.; Mytych, P.; Stasicka, Z. Homogeneous photocatalysis by transition metal complexes in the environment. $J$. Mol. Catal. A: Chem. 2004, 224, 17-33.

(3) Armaroli, N.; Accorsi, G.; Cardinali, F.; Listorti, A. Photochemistry and Photophysics of Coordination Compounds: Copper. In Photochemistry and Photophysics of Coordination Compounds I. Topics in Current Chemistry; Balzani, V.; Campagna, S., Eds.; Springer: Berlin, Heidelberg, 2007; 280, pp 69-115.

(4) Jiang, Q.; Xiao, N.; Shi, P.; Zhu, Y.; Guo, Z. Design of artificial metallonucleases with oxidative mechansim. Coord. Chem. Rev. 2007, 251, 1951-1972.

(5) Isaeva, E. I.; Gorbunova, V. V. Formation of copper-containing particles on the quartz surface as a result of the photolysis of copper(II) complexes with amino acids. Russ. J. Gen. Chem. 2017, 87, $2852-2857$.

(6) Ndungu, K.; Hurst, M. P.; Bruland, K. W. Comparison of copper speciation in estuarine water measured using analytical voltammetry and supported liquid membrane techniques. Environ. Sci. Technol. 2005, 39, 3166-3175.

(7) Ndungu, K. Model predictions of copper speciation in coastal water compared to measurements by analytical voltammetry. Environ. Sci. Technol. 2012, 46, 7644-7652.

(8) Craven, A. M.; Aiken, G. R.; Ryan, J. N. Copper(II) binding by dissolved organic matter: Importance of the copper-to-dissolved organic matter ratio and implications for the biotic ligand model. Environ. Sci. Technol. 2012, 46, 9948-9955.

(9) Buck, K. N.; Moffett, J.; Barbeau, K. A.; Bundy, R. M.; Kondo, Y.; $\mathrm{Wu}, \mathrm{J}$. The organic complexation of iron and copper: An intercomparison of competitive ligand exchange-adsorptive cathodic stripping voltammetry (CLE-ACSV) techniques. Limnol. Oceanogr. Methods 2012, 10, 496-515.

(10) Takamura-Enya, T.; Tokutake, M. Novel speciation analysis of copper in river water: Observation of soluble anionic copper-ligand complexes. Limnology 2016, 17, 117-125.

(11) Wong, K. H.; Obata, H.; Kim, T.; Wakuta, Y.; Takeda, S. Distribution and speciation of copper and its relationship with FDOM in the East China Sea. Mar. Chem. 2019, 212, 96-107.

(12) Buerge-Weirich, D.; Sulzberger, B. Formation of $\mathrm{Cu}(\mathrm{I})$ in estuarine and marine waters: application of a new solid-phase extraction method to measure Cu(I). Environ. Sci. Technol. 2004, $38,1843-1848$

(13) Kieber, R. J.; Skrabal, S. A.; Smith, C.; Willey, J. D. Redox speciation of copper in rainwater: Temporal variability and atmospheric deposition. Environ. Sci. Technol. 2004, 38, 3587-3594.
(14) Witt, M. L. I.; Skrabal, S.; Kieber, R.; Willey, J. Photochemistry of $\mathrm{Cu}$ complexed with chromophoric dissolved organic matter: Implications for $\mathrm{Cu}$ speciation in rainwater. J. Atmos. Chem. 2007, 58, 89-109.

(15) Zitoun, R.; Clearwater, S. J.; Hassler, C.; Thompson, K. J.; Albert, A.; Sander, S. G. Copper toxicity to blue mussel embryos (Mytilus galloprovincialis) The effect of natural dissolved organic matter on copper toxicity in estuarine waters. Sci. Total Environ. 2019, 653, 300-314.

(16) Bushaw, K. L.; Zepp, R. G.; Tarr, M. A.; Schulz-Jander, D.; Bourbonniere, R. A.; Hodson, R. E.; Miller, W. L.; Bronk, D. A.; Moran, M. A. Photochemical release of biologically available nitrogen from aquatic dissolved organic matter. Nature 1996, 381, 404-407.

(17) Tarr, M. A.; Wang, W.; Bianchi, T. S.; Engelhaupt, E. Mechanisms of ammonia and amino acid photoproduction from aquatic humic and colloidal matter. Water Res. 2001, 35, 3688-3696.

(18) Matsumoto, K.; Uematsu, M. Free amino acids in marine aerosols over the western North Pacific Ocean. Atmos. Environ. 2005, 39, 2163-2170.

(19) Vähätalo, A. V.; Zepp, R. G. Photochemical mineralization of dissolved organic nitrogen to ammonium in the Baltic Sea. Environ. Sci. Technol. 2005, 39, 6985-6992.

(20) Kitidis, V.; Uher, G.; Upstill-Goddard, R. C.; Mantoura, R. F. C.; Spyres, G.; Woodward, E. M. S. Photochemical production of ammonium in the oligotrophic Cyprus Gyre (Eastern Mediterranean). Biogeosciences 2006, 3, 439-449.

(21) Mandalakis, M.; Apostolaki, M.; Tziaras, T.; Polymenakou, P.; Stephanou, E. G. Free and combined amino acids in marine background atmospheric aerosols over the Eastern Mediterranean. Atmos. Environ. 2011, 45, 1003-1009.

(22) Chu, C.; Lundeen, R. A.; Sander, M.; McNeill, K. Assessing the indirect photochemical transformation of dissolved combined amino acids through the use of systematically designed histidine-containing oligopeptides. Environ. Sci. Technol. 2015, 49, 12798-12807.

(23) Vasilevich, R. S.; Beznosikov, V. A. Amino acid composition of humic substances in tundra soils. Eurasian Soil Sci. 2015, 48, 593599.

(24) Matos, J. T. V.; Duarte, R. M. B. O.; Duarte, A. C. Challenges in the identification and characterization of free amino acids and proteinaceous compounds in atmospheric aerosols: A critical review. TrAC, Trends Anal. Chem. 2016, 75, 97-107.

(25) Morel, F. M. M.; Price, N. M. The biogeochemical cycles of trace metals in the oceans. Science 2003, 300, 944-947.

(26) Hsu-Kim, H. Stability of metal-glutathione complexes during oxidation by hydrogen peroxide and $\mathrm{Cu}(\mathrm{II})$-catalysis. Environ. Sci. Technol. 2007, 41, 2338-2342.

(27) Zhang, G.; Liang, S.; Shi, X.; Han, X. Dissolved organic nitrogen bioavailability indicated by amino acids during a diatom to dinoflagellate bloom succession in the Changjiang River estuary and its adjacent shelf. Mar. Chem. 2015, 176, 83-95.

(28) Boreen, A. L.; Edhlund, B. L.; Cotner, J. B.; McNeill, K. Indirect photodegradation of dissolved free amino acids: The contribution of singlet oxygen and the differential reactivity of DOM from various sources. Environ. Sci. Technol. 2008, 42, 54925498.

(29) Remucal, C. K.; McNeill, K. Photosensitized amino acid degradation in the presence of riboflavin and its derivatives. Environ. Sci. Technol. 2011, 45, 5230-5237.

(30) Zhang, Y.; Zhang, R.; Li, S. L.; Mostofa, K. M. G.; Fu, X.; Ji, H.; Liu, W.; Sun, P. Photo-ammonification of low molecular weight dissolved organic nitrogen by direct and indirect photolysis. Sci. Total Environ. 2021, 764, No. 142930.

(31) Ferraudi, G.; Muralidharan, S. Photochemical properties of copper complexes. Coord. Chem. Rev. 1981, 36, 45-88.

(32) Natarajan, P.; Ferraudi, G. Photochemical properties of copper(II)-amino acid complexes. Inorg. Chem. 1981, 20, 3708-3712.

(33) Namasivayam, C.; Natarajan, P. Photopolymerization reactions initiated by copper(II)-amino acid chelates: Investigation of the 
initiating species by flash photolysis. I. J. Polym. Sci.: Polym. Chem. Ed. 1983, 21, 1371-1384.

(34) Das, S.; Johnson, G. R. A.; Nazhat, N. B.; Saadalla-Nazhat, R. Ligand decomposition in the photolysis of copper(II)-amino-acid complexes in aqueous solution. J. Chem. Soc., Faraday Trans. I 1984, 80, 2759-2766.

(35) Faust, B. C. Aquatic Photochemical Reactions in Atmospheric, Surface, and Marine Waters: Influences of Oxidant Formation and Pollutant Degradation. In Environmental Photochemistry. The Handbook of Environmental Chemistry; Boule, P., Ed.; Springer-Verlag: Berlin, Heidelberg, 1999; Vol. 2, Part L, pp 101-122.

(36) Lin, C. J.; Hsu, C. S.; Wang, P. Y.; Lin, Y. L.; Lo, Y. S.; Wu, C. $\mathrm{H}$. Photochemical redox reactions of copper(II)-alanine complexes in aqueous solutions. Inorg. Chem. 2014, 53, 4934-4943.

(37) Pan, Y.; Garg, S.; Waite, T. D.; Yang, X. Copper inhibition of triplet-induced reactions involving natural organic matter. Environ. Sci. Technol. 2018, 52, 2742-2750.

(38) Wan, D.; Sharma, V. K.; Liu, L.; Zuo, Y.; Chen, Y. Mechanistic insight into the effect of metal ions on photogeneration of reactive species from dissolved organic matter. Environ. Sci. Technol. 2019, 53, $5778-5786$.

(39) Pan, Y.; Ruan, X.; Garg, S.; Waite, T. D.; Lei, Y.; Yang, X. Copper inhibition of triplet-sensitized phototransformation of phenolic and amine contaminants. Environ. Sci. Technol. 2020, 54, 9980-9989.

(40) Subramanian, G.; Prakash, H. Photo augmented copper-based Fenton disinfection under visible LED light and natural sunlight irradiation. Water Res. 2021, 190, No. 116719.

(41) Smith, R. M.; Martell, A. E. Critical Stability Constants; Plenum: New York, 1976-1989; pp 1-6.

(42) Martell, A. E.; Smith, R. M.; Motekaitis, R. J. NIST Standard Reference Database 46: NIST Critically Selected Stability Constants of Metal Complexes, Version 7.0; NIST: Gaithersburg, MD, 2003.

(43) Faust, B. C. Experimental determination of molar absorptivities and quantum yields for individual complexes of a labile metal in dilution solution. Environ. Sci. Technol. 1996, 30, 1919-1922.

(44) Solomon, E. I. Spectroscopic methods in bioinorganic chemistry: Blue to green to red copper sites. Inorg. Chem. 2006, 45, 8012-8025.

(45) Koebke, K. J.; Alfaro, V. S.; Pinter, T. B. J.; Deb, A.; Lehnert, N.; Tard, C.; Penner-Hahn, J. E.; Pecoraro, V. L. Traversing the redgreen-blue color spectrum in rationally designed cupredoxins. J. Am. Chem. Soc. 2020, 142, 15282-15294.

(46) Sun, L.; Wu, C. H.; Faust, B. C. Photochemical redox reactions of inner-sphere copper(II)-dicarboxylate complexes: Effects of the dicarboxylate ligand structure on copper(I) quantum yields. J. Phys. Chem. A 1998, 102, 8664-8672.

(47) Wu, C. H.; Sun, L.; Faust, B. C. Photochemical formation of copper(I) from copper(II)-dicarboxylate complexes: Effects of outersphere versus inner-sphere coordination and of quenching by malonate. J. Phys. Chem. A 2000, 104, 4989-4996.

(48) Goodman, B. A.; McPhail, D. B.; Powell, H. K. J. Electron spin resonance study of copper(II)-amino-acid complexes: Evidence for cis and trans isomers and the structures of copper(II)-histidinate complexes in aqueous solution. J. Chem. Soc., Dalton Trans. 1981, 822-827.

(49) Bukharov, M. S.; Shtyrlin, V. G.; Mukhtarov, A. S.; Mamin, G. V.; Stapf, S.; Mattea, C.; Krutikov, A. A.; Ilin, A. N.; Serov, N. Y. Study of structural and dynamic characteristics of copper(II) amino acid complexes in solutions by combined EPR and NMR relaxation methods. Phys. Chem. Chem. Phys. 2014, 16, 9411-9421.

(50) Poutsma, M. L. The radical stabilization energy of a substituted carbon-centered free radical depends on both the functionality of the substituent and the ordinality of the radical. J. Org. Chem. 2011, 76, $270-276$.

(51) Hioe, J.; Zipse, H. Radical Stability-Thermochemical Aspects. In Encyclopedia of Radicals in Chemistry, Biology and Materials, Vol. 1, Basic Concepts and Methodologies; Chatgilialoglu, C.; Studer, A., Eds.; John Wiley \& Sons: Chichester, UK, 2012; pp 449-476.
(52) Zipse, H. Radical Stability-A Theoretical Perspective. In Radicals in Synthesis I. Topics in Current Chemistry; Gansauer, A., Ed.; Springer: Berlin, Heidelberg, 2006; 263, pp 163-189.

(53) Hioe, J.; Zipse, H. Radical stability and its role in synthesis and catalysis. Org. Biomol. Chem. 2010, 8, 3609-3617.

(54) Luo, Y. R. Comprehensive Handbook of Chemical Bond Energies; CRC Press: Boca Raton, FL, 2007.

(55) Lundeen, R. A.; Janssen, E. M. L.; Chu, C.; McNeill, K. Environmental photochemistry of amino acids, peptides and proteins. Chimia 2014, 68, 812-817.

(56) Sharma, V. K.; Millero, F. J. Oxidation of copper(II) in seawater. Environ. Sci. Technol. 1988, 22, 768-771.

(57) Gustafsson, J. P. MINTEQA2 version 4.0 and Visual MINTEQ version 3.0; Department of Land and Water Resources Engineering, Royal Institute of Technology (KTH): Stockholm, Sweden, 2012

(58) Allison, J. D.; Brown, D. S.; Novo-Gradac, K. J.. MINTEQA2/ PRODEFA2, A Geochemical Assessment Model for Environmental Systems. Version 4.0; EPA/600/3-91/021; U.S. Environmental Protection Agency: Athens, GA, 1999.

(59) Lomozová, Z.; Catapano, M. C.; Hrubša, M.; Karlíčková, J.; Macáková, K.; Kučera, R.; Mladěnka, P. Chelation of iron and copper by quercetin B-ring methyl metabolites, isorhamnetin and tamarixetin, and their effect on metal-based Fenton chemistry. J. Agric. Food Chem. 2021, 69, 5926-5937.

(60) Wang, P. Y.; Wu, J. Y.; Chen, H. J.; Lin, T. Y.; Wu, C. H. Purgeand-trap ion chromatography for the determination of trace ammonium ion in high-salinity water samples. J. Chromatogr. A 2008, 1188, 69-74.

(61) Lin, T. Y.; Pan, Y. T.; Lee, H. Y.; Wang, P. Y.; Wu, C. H. Markedly enhanced purge-and-trap performance and efficiency for the determination of ammonium ion in high-salinity water samples. $J$. Chin. Chem. Soc. 2012, 59, 718-726.

(62) Lin, Y. L.; Wang, P. Y.; Hsieh, L. L.; Ku, K. H.; Yeh, Y. T.; Wu, C. H. Determination of linear aliphatic aldehydes in heavy metal containing waters by high-performance liquid chromatography using 2,4-dinitrophenylhydrazine derivatization. J. Chromatogr. A 2009, 1216, 6377-6381.

(63) Galbavy, E. S.; Ram, K.; Anastasio, C. 2-Nitrobenzaldehyde as a chemical actinometer for solution and ice photochemistry. $J$. Photochem. Photobiol., A 2010, 209, 186-192.

(64) Leifer, A. The Kinetics of Environmental Aquatic Photochemistry: Theory and Practice; ACS Professional Reference Book, American Chemical Society: Washington, DC, 1988. 